\title{
Crosslinking-mediated activation of the FceRI: Does it need antigen for success?
}

\author{
Michael HUBER ${ }^{\star}$; SANDRo CAPELLMANN \\ Institute of Biochemistry and Molecular Immunology, Medical Faculty, RWTH Aachen University, Aachen, 52074, Germany
}

Key words: Mast cell, FceRI, Rafts, Transmembrane proteins, Virus receptor

\begin{abstract}
Mast cells (MCs), hematopoietic cells of the myeloid lineage, are well-known for their pro-inflammatory nature contributing to the development of various allergic and autoimmune diseases. One of the characteristic receptors on MCs, the high-affinity receptor for IgE (FceRI), is activated in its IgE-bound state via binding and crosslinking by polyvalent antigen. This results in its phosphorylation by the SRC family kinase LYN, initiating differential signaling pathways, eventually triggering immunological effector functions, such as degranulation and cytokine production. Few publications have reported on FceRI-dependent but antigen-independent MC activation by antibody-mediated crosslinking of membrane molecules (e.g., transmembrane proteins and glycosphingolipids) that are both localized in membrane rafts and in close vicinity to the FceRI. In this Viewpoint we will briefly introduce FceRI-mediated MC stimulation, cite examples of FceRI-proximal molecules, the crosslinking of which can cause FceRI-dependent MC activation, and discuss the potential of certain viruses as well as auto-antibodies to act as indirect FceRI-crosslinking agents. In latter cases, antigen-independent FceRI-mediated pro-inflammatory MC activation could contribute to the development of detrimental cytokine storms.
\end{abstract}

\section{Introduction}

Mast cells (MCs) are innate immune cells and belong to the hematopoietic lineage. They are strategically located at the borders between self and environment of eukaryotic organisms, particularly in skin, lung and gastrointestinal tract (Metz and Maurer, 2007; Huber et al., 2019). Though being evolutionary older than the adaptive immune system, MCs are endowed with immunoglobulin-binding $\mathrm{Fc}$ receptors, among which the high-affinity receptor for IgE (FceRI) is one of the most characteristic MC receptors. The FceRI belongs to the family of multichain immune recognition receptors (MIRRs). It comprises an IgE-binding $\alpha$-chain, a signal-modulating tetraspanin $\beta$-chain, and a disulfide-bridged signal-generating $\gamma$-chain homodimer. Both $\beta$ - and $\gamma$-chains contain so-called ITAMs (immunoreceptor tyrosine-based activation motifs), which are phosphorylated by the tyrosine kinase LYN upon receptor stimulation (Fig. 1A). Concerning these initial tyrosine phosphorylation events that spark the downstream IgE-mediated signaling and effector processes, three models are discussed, which most likely are not mutually exclusive: i) the transactivation model,

*Address correspondence to: Michael Huber, mhuber@ukaachen.de Received: 30 July 2021; Accepted: 08 October 2021 ii) the lipid raft model, and iii) the kinase-phosphatase interplay model (Bugajev et al., 2010). In principle, FceRI stimulation can be provoked via crosslinking of the IgEbound FceRI by polymeric antigens (Fig. 1B), eventually triggering several intricately interconnected signaling pathways (e.g., phosphatidylinositol-3-kinase (PI3K) pathway, phospholipase C- $\gamma$ (PLC- $\gamma$ ) pathway, and mitogen-activated protein kinase (MAPK) pathways). Antigen-triggered MCs immediately release preformed mediators (e.g., proteases, histamine, and proteoglycans) stored in secretory lysosomes in a process called degranulation, and de novo synthesize arachidonic acid metabolites (e.g., leukotrienes and prostaglandins) as well as various cytokines and chemokines such as IL- 6 and TNF. Regarding this direct crosslinking-mediated mechanism of FceRI activation triggered by polyvalent antigens, it is tempting to speculate that indirect crosslinking of single FceRI complexes provoked by the aggregation of raftlocalized transmembrane proteins proximal to the FceRI might result in MC activation, as well.

\section{A First Proof of Principle}

Compared to other MIRRs like the B- and T-cell receptors, the number of established co-receptors for the FceRI is considerably smaller. Thus, several studies were undertaken, 
B

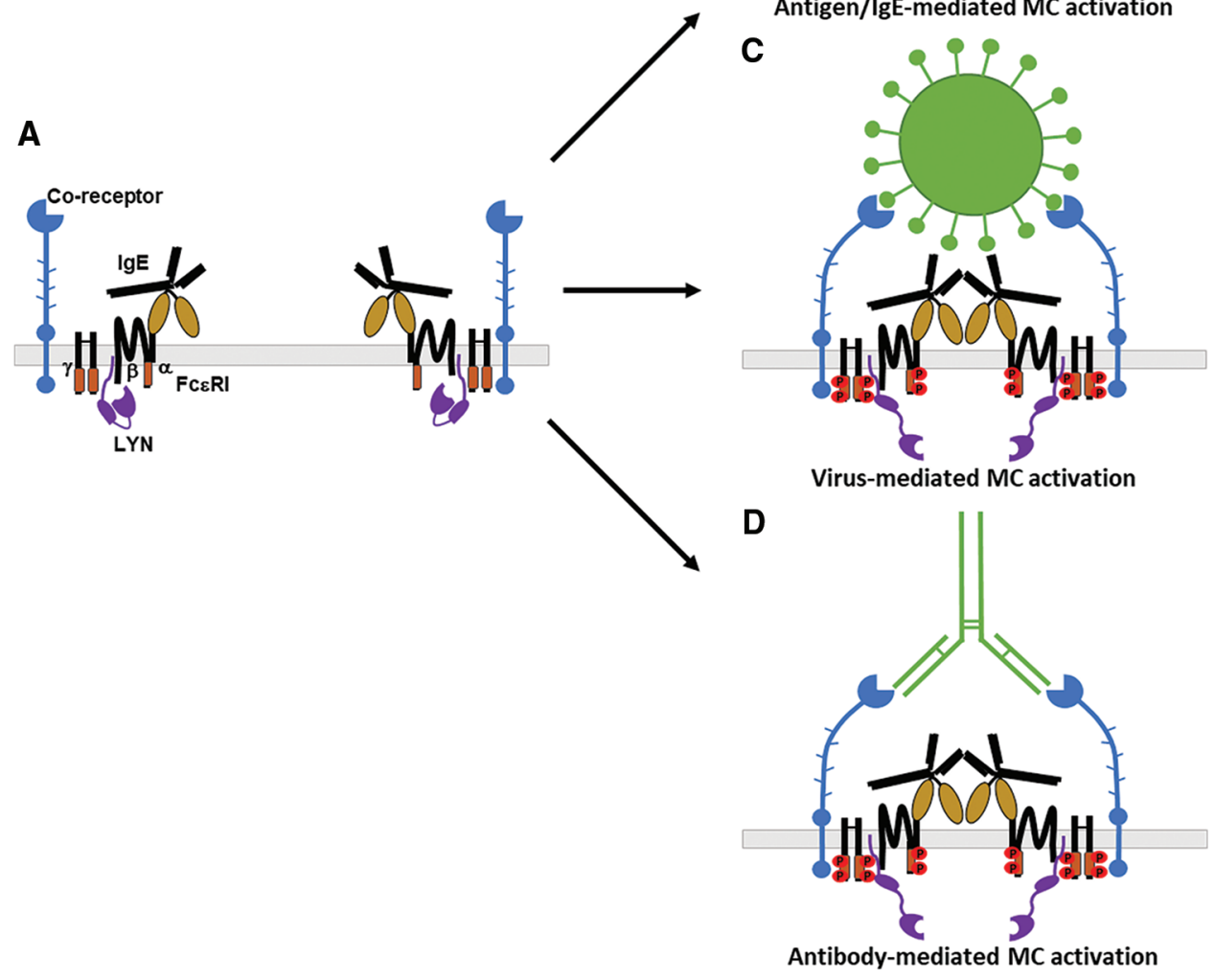

FIGURE 1. Well-known antigendependent and potential antigenindependent FceRI-mediated mast cell activation. In the resting state, single FceRI complexes consisting of the $\alpha, \beta$, and $\gamma$ subunits are located in the plasma membrane, pre-associated with the SRC family kinase LYN and (various) coreceptors (A). IgE-dependent binding to polyvalent antigens induces the canonical FceRI activation followed by LYN-dependent phosphorylation of ITAMs in the $\beta$ and $\gamma$ subunits (B). Activation of the FceRI could be achieved by crosslinking of associated co-receptors that bind polyvalent antigens, like viruses $(\mathrm{C})$, or by coreceptor-targeting antibodies (D). Depending on the epitope, which the crosslinking antibody recognizes, or the type of targeted co-receptor, these non-canonical ways of FceRI activation do or do not require $\operatorname{IgE}$ bound to the a chain. in which antibodies against $\mathrm{MC}$ membrane structures were produced to be analyzed with respect to their MC activating or suppressing potential either when applied alone or when used for stimulation in combination with antigen. Schwarz et al. (2000) raised respective monoclonal antibodies by immunizing mice with membrane preparations of the rat MC line RBL-2H3 and tested for their potency to influence FceRI-triggered MC activation. Intriguingly, one of these antibodies (belonging to the IgM class) was able to induce degranulation of IgE-preloaded MCs in an antigenindependent manner. However, this antibody did not bind to any FceRI-interacting membrane protein but rather to four types of glycosphingolipids. This fits perfectly into the plethora of data describing the importance of glycosphingolipid/cholesterol-rich membrane domains (socalled rafts) for antigen-triggered activation of the FceRI (Varshney et al., 2016). Thus, co-aggregation of IgE-loaded FceRI by the glycosphingolipid-specific antibody sufficed to initiate signaling mechanisms necessary for induction of the secretion process. Importantly, these data indicated that productive crosslinking of IgE-loaded FceRI does not only depend on IgE-specific antigen but can also be promoted by aggregation of FceRI-interacting or proximal membrane molecules. This suggests that crosslinking of FceRI-associated, raft-localized transmembrane proteins in physiological or pathophysiological settings could be capable of fueling inflammatory processes by triggering MC degranulation, arachidonic acid metabolism and/or cytokine secretion. Such antigen-independent crosslinking might be accomplished by auto-antibodies against these FceRI-associated membrane proteins or by other multivalent ligands binding to such proteins.

\section{Viruses and Auto-Antibodies as Potential FceRI-Dependent MC Activators}

Particularly viruses, being evolutionary-perfected multivalent antigens, would have what it takes to activate MCs in an FceRI-dependent but antigen-independent manner, potentially promoting the contribution of MCs to the development of pathological cytokine storms in the course of virus infections. In an endeavor to find novel FceRI-interacting proteins, potentially exerting co-receptor activities, we identified CD13/ aminopeptidase $\mathrm{N}$ as an FceRI-interacting membrane protein and a negative regulator of MC activation (Zotz et al., 2016). CD13 was co-internalized upon antigen-mediated FceRI triggering, verifying close proximity of these raft-associated proteins. Remarkably, a CD13-specific monoclonal antibody induced pro-inflammatory cytokine production and secretion in IgE-loaded murine bone marrow-derived MCs (BMMCs) in 
a strictly FceRI-dependent manner (Fig. 1D). Moreover, the antiCD13 antibody synergistically enhanced antigen-triggered cytokine production (Zotz et al., 2016). This raised the question if CD13-mediated FceRI crosslinking can be of any physiological or pathophysiological relevance. Though not proven yet, it appears interesting that in humans CD13 acts as receptor for coronavirus 229E that causes upper respiratory tract infections (Yeager et al., 1992). Hence, the occurrence of an infection with coronavirus 229E might be able to aggravate IgE-driven allergic diseases via interaction with $\mathrm{CD} 13$ and consequent indirect crosslinking of the FceRI (Fig. 1C). Moreover, production of CD13-specific auto-antibodies was reported in bone marrow-transplanted, cytomegalovirus-positive patients (Rahbar et al., 2006). This suggests that auto-antibodies raised against membrane proteins, which have been caught in viral membranes during virus budding, in principle can have what it takes to bind and crosslink these membrane proteins. Given that such auto-antibodies concern FceRI-proximal MC proteins, $\mathrm{MC}$ activation might be the consequence. Intriguingly, in a very recent study, Wang et al. (2021) analyzed a cohort of 194 SARS-CoV-2 infected COVID-19 patients for autoantibodies against proteins of the so-called exoproteome, including cell surface proteins. Compared to healthy controls, COVID-19 patients exhibited drastic increases in auto-antibodies against immunomodulatory proteins. Given that such proteins are raft-localized in MCs, respective antibodies could drive inflammation via indirect FceRI crosslinking and activation, and thus contribute to the generation of detrimental cytokine storms in severe cases of COVID-19.

Along these lines, CD26, a.k.a. dipeptidyl peptidase IV (DPP4), which was recently identified on human skin MCs (Gschwandtner et al., 2017), has been demonstrated to act as a functional receptor for the MERS coronavirus (hCoV-EMC) (Raj et al., 2013). Fitting to the localization of the FceRI, CD26 in T lymphocytes is expressed in lipid rafts. Moreover, it has been shown that crosslinking of $\mathrm{CD} 26$ by anti-CD26 antibodies can cause co-aggregation of the transmembrane tyrosine phosphatase $\mathrm{CD} 45$ in lipid rafts, hence promoting activation of the tyrosine kinase LCK mandatory for T cell antigen receptor activation (Ishii et al., 2001). Though MCs express several SRC family kinases, LCK is not amongst them; however, one of the central functions of LCK in T cells, namely to phosphorylate the ITAMs in the $\mathrm{CD} 3$ chains of the $\mathrm{T}$ cell antigen receptor, is taken on by LYN in MC FceRI signaling, which is also dephosphorylated by $\mathrm{CD} 45$ at its $\mathrm{C}$-terminal inhibitory tyrosine residue, and thus activated to phosphorylate the ITAMs of the FceRI $\beta$ - and $\gamma$-chains (Bugajev et al., 2010). In line with a positive regulatory role of CD45, murine MCs deficient for CD45 show dramatic attenuation of antigen-triggered degranulation and cytokine production (Grochowy et al., 2009). Interestingly, it has been demonstrated that human skin MCs secrete an active form of CD26 (Gschwandtner et al., 2017), which would suggest the possibility of release of an endogenous competitor against MERS coronavirus binding to MCs.

Also of interest and in line with the topic of this viewpoint, the glycoprotein 120 (gp120) of human HIV-1 is an immunoglobulin superantigen, which interacts with the heavy chain variable $3\left(\mathrm{~V}_{\mathrm{H}} 3\right)$ regions of human immunoglobulins, and was shown to activate IgE-bound human lung MCs to the release of proinflammatory factors (Marone et al., 2020). FceRI-mediated MC activation can be induced by shed gp120, and gp120 is suggested to crosslink $\mathrm{V}_{\mathrm{H}}$ 3-positive IgE-loaded FceRI in its virus-bound form (Marone et al., 2001).

\section{FceRI-Associated Proteins as Boosters of Mast Cell Activation}

MC activation by use of antibodies against non-FceRI transmembrane proteins as well as enhancement of antigentriggered MC effector functions by such antibodies was found for the T-cell immunoglobulin and mucin domain-containing protein 3 (TIM-3), a protein described as an immune checkpoint receptor on various immune cells as well as leukemic stem cells (Wolf et al., 2020). TIM-3 is constitutively expressed on mouse peritoneal MCs (PMCs) and BMMCs (Nakae et al., 2007), and its expression has been demonstrated to be upregulated in human cord bloodderived MCs upon TGF- $\beta$ stimulation (Wiener et al., 2007). Interestingly, whereas in two studies polyclonal antibodies against TIM-3 have been found to promote the production of various cytokines (IL-4, IL-6 and IL-13) (Nakae et al., 2007; Phong et al., 2015), only in the study by Phong et al. also monoclonal anti-TIM-3 antibodies were capable of promoting antigen-triggered production of cytokines. Of note, different clones of monoclonal antibodies were used in these studies, indicating that location of the respective epitope within the TIM-3 molecule and antibody-evoked conformational changes, amongst others are crucial for their stimulatory capacity. Further analyses demonstrated that TIM-3 constitutively interacted with the FceRI signaling subunits and was co-internalized with the FceRI upon antigen stimulation, consistent with a close physical and functional association between TIM-3 and the FceRI (Phong et al., 2015). As mentioned above, TIM-3 can act as an immune checkpoint receptor, and the co-blockade of TIM-3 and the transmembrane protein programmed cell death protein 1 (PD-1) has been shown to attenuate tumor progression in different preclinical models (Acharya et al., 2020). Meanwhile different clinical trials using anti-TIM-3 antibodies have been initiated, either using TIM-3-specific antibodies as monotherapy or as combined therapy with antiPD-1 antibodies or further chemotherapeutic agents (Acharya et al., 2020). It will be interesting to see whether MC activation-associated effects will be measured, particularly in allergic patients.

While anti-CD13 antibodies were able to activate BMMCs in an FceRI-dependent but antigen-independent manner and cause considerably enhanced activation when co-applied with antigen (Zotz et al., 2016), anti-TIM-3 antibodies only showed MC stimulating effects when used in combination with antigen. Though treatment with antiTIM-3 antibodies alone did not impact on phosphorylation/ activation of PLC- $\gamma$, a significant effect was measured upon co-stimulation with antigen and anti-TIM-3 antibodies. This suggests that TIM-3 integrates its signals into the signaling processes triggered by the FceRI (Phong et al., 2015). Interestingly, a comparable situation was found 
by Sibilano et al. (2016) who investigated the functional interaction between FceRI and the transmembrane protein TNF receptor superfamily 14 (TNFRSF14). The costimulation of MCs with antigen and the TNFRSF14 ligand, TNFSF14, resulted in strongly augmented MC signaling and production of various mediators, though TNFSF14 alone was without effect in these respects. In agreement with these data, a thorough confocal laser scanning microscopy analysis revealed a drastically increased number and size of FceRI-containing clusters on the MC surface upon FceRI and TNFRSF14 co-activation compared to activation of the FceRI alone (Sibilano et al., 2016). This clearly defined TNFRSF14 as a co-receptor of the FceRI. The ligand, TNFSF14, is assembled into a trimer, which is the basis for the clustering of its receptor, probably contributing to the enhanced aggregation of the co-activated FceRI.

\section{Conclusion}

Few but thorough studies have demonstrated that antibodymediated crosslinking of raft-localized, FceRI-proximal molecules, like transmembrane proteins or glycolipids, can result in FceRI-dependent MC activation. Though "crosslinking" is a concept comprehensible to many, productive crosslinking that results in successful receptor activation requires more than uncontrolled receptor aggregation. Allergens/antigens have to exert an optimal oligo-/polyvalency to form conjugates containing antigen, IgE, and FceRI of proper size and geometry. Studies using synthetic multivalent antigens of defined distance between their epitopes have demonstrated the importance of antigen size to promote MC activation (Tesfaye et al., 2021). Thus, most likely not every FceRI-proximal transmembrane protein bound by an antibody or a virus might have the right conformation or distance to the FceRI sufficient to induce mediator release. Moreover, the presence of IgE prebound to the FceRI or the co-stimulation with respective antigen can make a difference. Such mechanism of indirect FceRImediated MC activation, as described in this Viewpoint, might not be observable in every case where an FceRIproximal transmembrane protein is recognized by a virus or an auto-antibody. Nevertheless, these situations in which FceRI crosslinking is induced by auto-antibodies against FceRI-proximal transmembrane proteins or infections with viruses using such proteins as entry receptors, might result in pro-inflammatory MC activation that could contribute to the development of detrimental cytokine storms.

Acknowledgement: We thank Drs. M. Kuhny and T. Wilhelm for discussions and proof-reading of the manuscript.

Authors' Contribution: $\mathrm{MH}$ conceived and wrote the manuscript; SC discussed the topic and prepared the figure; both authors reviewed the manuscript.

Funding Statement: $\mathrm{MH}$ was supported by the Deutsche Forschungsgemeinschaft (DFG HU794/12-1).

Conflicts of Interest: The authors declare that they have no conflicts of interest to report regarding the present study.

\section{References}

Acharya N, Sabatos-Peyton C, Anderson AC (2020). Tim-3 finds its place in the cancer immunotherapy landscape. Journal for ImmunoTherapy of Cancer 8: e000911. DOI 10.1136/jitc2020-000911.

Bugajev V, Bambouskova M, Draberova L, Draber P (2010). What precedes the initial tyrosine phosphorylation of the high affinity IgE receptor in antigen-activated mast cell? FEBS Letters 584: 4949-4955. DOI 10.1016/j.febslet.2010.08.045.

Grochowy G, Hermiston ML, Kuhny M, Weiss A, Huber M (2009). Requirement for CD45 in fine-tuning mast cell responses mediated by different ligand-receptor systems. Cellular Signalling 21: 1277-1286. DOI 10.1016/j.cellsig.2009.03.018.

Gschwandtner M, Paulitschke V, Mildner M, Brunner PM, Hacker S, Eisenwort G, Sperr WR, Valent P, Gerner C, Tschachler E (2017). Proteome analysis identifies L1CAM/CD171 and DPP4/CD26 as novel markers of human skin mast cells. Allergy 72: 85-97. DOI 10.1111/all.12919.

Huber M, Cato ACB, Ainooson GK, Freichel M, Tsvilovskyy V, Jessberger R, Riedlinger E, Sommerhoff CP, Bischoff SC (2019). Regulation of the pleiotropic effects of tissueresident mast cells. Journal of Allergy and Clinical Immunology 144: 31-45. DOI 10.1016/j.jaci.2019.02.004.

Ishii T, Ohnuma K, Murakami A, Takasawa N, Kobayashi S, Dang NH, Schlossman SF, Morimoto C (2001). CD26-mediated signaling for $\mathrm{T}$ cell activation occurs in lipid rafts through its association with CD45RO. Proceedings of the National Academy of Science USA 98: 12138-12143. DOI 10.1073/pnas.211439098.

Marone G, Florio G, Petraroli A, de Paulis A (2001). Dysregulation of the IgE/FceRI network in HIV-1 infection. Journal of Allergy and Clinical Immunology 107: 22-30. DOI 10.1067/mai.2001.111589.

Marone G, Rossi FW, Pecoraro A, Pucino V, Criscuolo G, de Paulis A, Spadaro G, Marone G, Varricchi G (2020). HIV gp120 induces the release of proinflammatory angiogenic, and lymphangiogenic factors from human lung mast cells. Vaccines 8: 208. DOI 10.3390/vaccines8020208.

Metz M, Maurer M (2007). Mast cells-Key effector cells in immune responses. Trends in Immunology 28: 234-241. DOI 10.1016/ j.it.2007.03.003.

Nakae S, Iikura M, Suto H, Akiba H, Umetsu DT, Dekruyff RH, Saito H, Galli SJ (2007). TIM-1 and TIM-3 enhancement of Th2 cytokine production by mast cells. Blood 110: 2565-2568. DOI 10.1182/blood-2006-11-058800.

Phong BL, Avery L, Sumpter TL, Gorman JV, Watkins SC, Colgan JD, Kane LP (2015). Tim-3 enhances FceRI-proximal signaling to modulate mast cell activation. Journal of Experimental Medicine 212: 2289-2304. DOI 10.1084/jem.20150388.

Rahbar A, Boström L, Söderberg-Naucler C (2006). Detection of cytotoxic CD13-specific autoantibodies in sera from patients with ulcerative colitis and Crohn's disease. Journal of Autoimmunity 26: 155-164. DOI 10.1016/j.jaut.2006.02.003.

Raj VS, Mou H, Smits SL, Dekkers DH, Muller MA et al. (2013). Dipeptidyl peptidase 4 is a functional receptor for the emerging human coronavirus-EMC. Nature 495: 251-254. DOI 10.1038/nature12005.

Schwarz A, Jurgens L, Licht A, Schneider H, Futerman AH, Pecht I (2000). An IgE-dependent secretory response of mast cells can be induced by a glycosphingolipid-specific monoclonal antibody. European Journal of Immunology 30: 217-226. DOI 10.1002/(ISSN)1521-4141.

Sibilano R, Gaudenzio N, DeGorter MK, Reber LL, Hernandez JD et al. (2016). A TNFRSF14-FceRI-mast cell pathway contributes to 
development of multiple features of asthma pathology in mice. Nature Communications 7: 13696. DOI 10.1038/ncomms13696.

Tesfaye A, Rodriguez-Nogales A, Benede S, Fernandez TD, Paris JL et al. (2021). Nanoarchitectures for efficient IgE crosslinking on effector cells to study amoxicillin allergy. Allergy 76: 3183-3193. DOI 10.1111/all.14834.

Varshney P, Yadav V, Saini N (2016). Lipid rafts in immune signalling: Current progress and future perspective. Immunology 149: 13-24. DOI 10.1111/imm.12617.

Wang EY, Mao T, Klein J, Dai Y, Huck JD et al. (2021). Diverse functional auto antibodies in patients with COVID-19. Nature 595: 283-288. DOI 10.1038/s41586-021-03631-y.

Wiener Z, Kohalmi B, Pocza P, Jeager J, Tolgyesi G, Toth S, Gorbe E, Papp Z, Falus A (2007). TIM-3 is expressed in melanoma cells and is upregulated in TGF-beta stimulated mast cells. Journal of Investigative Dermatology 127: 906-914. DOI 10.1038/sj.jid.5700616.

Wolf Y, Anderson AC, Kuchroo VK (2020). TIM3 comes of age as an inhibitory receptor. Nature Reviews Immunology 20: 171185. DOI 10.1038/s41577-019-0224-6.

Yeager CL, Ashmun RA, Williams RK, Cardellichio CB, Shapiro LH, Look AT, Holmes KV (1992). Human aminopeptidase N is a receptor for human coronavirus 229E. Nature 357: 420-422. DOI 10.1038/357420a0.

Zotz JS, Wolbing F, Lassnig C, Kauffmann M, Schulte U, Kolb A, Whitelaw B, Muller M, Biedermann T, Huber M (2016). CD13/ aminopeptidase $\mathrm{N}$ is a negative regulator of mast cell activation. FASEB Journal 30: 2225-2235. DOI 10.1096/f.201600278. 